\title{
Indonesian National Power to Achieve the Global Maritime Fulcrum
}

\author{
Hendra Maujana Saragih \\ Universitas Nasional \\ hendramaujana@gmail.com
}

\author{
Ramlan Siregar \\ Universitas Nasional \\ ramlansiregar@gmail.com
}

\author{
El Amry Bermawi Putera \\ Universitas Nasional \\ elamry29@yahoo.com
}

\begin{abstract}
The aim of this paper is to describe national power of Indonesia which has great potential to be the global maritime fulcrum. That is very reasonable considering Indonesia geographical position in the equator line, between two continents (Asia and Australia) and the two oceans (Pacific and Indian). This countrygeographically is part of Southeast Asian nations. In order to become a global maritime fulcrum, the port system in Indonesia must be modernized in accordance with international standards so that the ports are more accessible for the international shipping activities and provide excellent services following the international standards. The five main pillars will be required to be implemented to make Indonesia becomethe global maritime fulcrum. The First is to redevelop Indonesian maritime culture. The second pillar is a commitment to safeguard and manage marine resources. The third is a commitment to encourage the development of maritime infrastructure and connectivity. The next is Maritime diplomacy to invite all Indonesian partners to work cooparetively in the maritime field. The last one is as a focal point for two oceans, Indonesia is obliged to build maritime defense forces. This is necessarily required to both safeguard the maritime sovereignty and wealth andsecure the maritime shipping. This agenda is extremely needed asthe focus of Indonesian government to accelerate the bright future to become the global maritime fulcrum.
\end{abstract}

Keywords: National Power, global maritime Fulcrum, maritime diplomacy

\section{INTRODUCTION}

Global Maritime Fulcrum Policy (GMF) became one of the main focuses in the national development during Jokowi - JK government. The focus is on Indonesia's national development based on marine activities. They are the enforcement of the sovereignty of the water territory of the Unitary of the Republic of Indonesia (NKRI), the revitalization of maritime economic sectors, the strengthening and development of maritime connectivity, the rehabilitation of environmental degradation and the conservation of biodiversity, and the enhancement of the quality and quantity of marine human resources (HR).
Looking at the conceptual basis of the maritime fulcrum pillars, the implementation of the maritime fulcrum concept should prioritize the implementation of sovereignty at sea. Then there need to be quick legal settlement of maritime boundaries and strengthening of marine defenses - ensuring deterrence and marine control to ensure marine activities run well.

After some literature reviews, the authors decided to implement two theories as a foundation of analysis. They are national power and maritime Fulcrum.

Based on National Power Theory, power has always been a very pivotal concept in the study of international relations. Power is a must to understand the nature and dynamics of power. How power can affect the behavior of individuals, groups and nations. According to Hans J. Morgenthau, National Forces are divided into several aspects, including geographical factors, natural resources, industrial capabilities, military alert, population, national character, and diplomacy quality.

Global Maritime Fulcrum (GMF) is a terminology expressed by President Jokowi when elaborating his vision and mission program during the presidential election campaign and when inaugurated as the seventh President of the Republic of Indonesia. In fact, the marine issues have long been reviewed and discussed in various seminars and scientific meetings involving various stakeholders.

From what has been formulated above, the proposed subject of this paper is: "How is Indonesia's Power in Realizing the Global Maritime Fulcrum?"

The research urgency is an attempt to know Indonesia's National Policy in Realizing the Global Maritime Fulcrum.

This research, of course, aims to determine the beginning of the Global Maritime Fulcrum by President Jokowi. Then it attempts to identify serious efforts made by the government in order to achieve the Fulcrum of maritime world

\section{METHOD}

The method of the study was descriptive qualitative method. David Williams stated research using the natural setting with the intention to interpret the phenomenon occuring and conducted with various methods can be used to interpret phenomena and utilized for qualitative research with various research methods. In qualitative 
research, the methods normally are interviews, observations, and utilization of documents.

\section{RESULT}

\section{Redevelopment of Indonesian maritime culture.}

Considering that maritime country is a country capable of utilizing and managing the sea space and natural wealth and its strategic location with its technology, science and equipment capability, Indonesia's challenges in its efforts to strengthenits status towards maritime nations should be supported. Consequently, the country coulddesign and build ability to accelerate the maritime progress for national interests. Therefore, the public needs to be aware and cares about various maritime security issues that may threaten the national maritim sovereigntyand stability.

\section{Commitment to safeguard and manage marine resources}

The first step isthe governmentneed to solve current maritime issues. According to Mr. President, among the maritime issues that still envelop our country are infrastructure, regulation, bad bureaucracy,etc. Those all hamper the pace of national maritime development.

Several years earlier, Indonesia launched a master plan for long-term economic development, known as the Master plan of Economic Acceleration and Expansion of Indonesia (MP3EI). MP3EI is an ambitious plan, aiming to push Indonesia into the top ten economies by 2025 . The plan has three pillars: the development of economic corridors or centers of growth, strengthening connectivity and human resource development, andnational science and technology.

To facilitate the movement of goods, services and people across the country, MP3EI aims to strengthen state connectivity. These encompass development of national logistics systems, national transportation systems, and information and communication technologies.

MP3EI also recognizes that Indonesia can no longer rely solely on the availability of cheap labor. It is undeniable that Indonesia should strengthen the knowledge-based economy that relies primarily on innovation as an engine of economic growth. This, in turn, requires a large collection of highly educated and skilled workforce, and hence the development of human resources should be one of the main priorities.

Like MSR, GMF still needs to be elaborated further. Nevertheless, in terms of what has been said so far, among others, the construction of tolls and possibly maritime-based economy would be highlighted. The development of the toll road is expected to include the development of ports in various different regions of Indonesia as well as the expansion and modernization of the country's shipping industry. Meanwhile, the marinebased economy also includes, among other components, the development of ships / vessels, infrastructure and repair and maintenance services, fishing, offshore oil exploration and extraction, resource extraction and utilization, marine tourism and recreational activities, and sea environmental management. The GMF initiative is also expected to include support for national connectivity development programs. Those are to facilitate the movement of goods, services and people across the country.

GMF is essentially a 'rediscovery' of Indonesian identity as a maritime country. For a long time, Indonesia was mismanaged as if it were a continental country. In fact, Indonesia comprise 17000 islands, between 2000 and 4000 of which are inhabited. In addition, about twothirds of the country's territory is water.

\section{Commitment to encourage the development of maritime infrastructure and connectivity.}

The concept of sea tolls can address the main problems of sea transportation related to the imbalance volume of goods transport between the western and eastern regions of Indonesia. This concept can be an effective solution in preventing the sailing of empty vessels from one place to another and is expected to create an efficient and integrated goods distribution system. The high cost of Indonesia logistics becomes a burden for logistics service providers, which also affectthe manufacturing companies. Transportation cost arises from the process of supplying raw materials to the most downstream processes of the supply chain, the delivery of finished goods to consumers. Inefficiencies and limitations of facilities in port activities cause many additional costs to be incurred.

Determination of zonation plans by local governments by taking into account the characteristics of local communities will make the existence of local communities not easily eroded by the modernization of development.

The maritime connectivity policy in the form of sea toll construction has a focus and a target. The focus in 2014 is to meet the needs of pioneer shipping, while the target in the fifth year is to realize a sea transportation system able to reduce logistics costs up to 20 percent of gross domestic revenue, grow a national shipping fleet from 10 to 30 percent, rejuvenate national vessels by setting apart ships over 25 years from 70 percent to 50 percent, and reduce port service time at major ports from 6 to 7 days to 3 to 4 days. This target is most likely to be achieved, if a number of important steps are taken, particularly crosssectorial planning, and involving local governments and communities.

\section{Indonesian Maritime Diplomacy}

President Joko Widodo then invited many countries to cooperate for the project and jointly deal with marine conflicts such as violations of sea sovereignty, illegal fishing, piracy and pollution issues. Regardingthe infrastructure development, it is projected that the Global Maritime Fulcrum is estimated require 70 trillion rupiah (or US \$ 5.6 million). Thus Indonesia is very open to have a cooperation and channeling of funds from various different countries, in particular China which also has maritime projects as contained in the MSR. Therefore, Indonesia agreed to join the AIIB and proposed as one of the founding countries, so the funds needed to achieve 
the Global Maritime Fulcrum could be obtained from Chinese aid, shared budgets among donor countries / other investors, or wholly financed from AIIB funding.

\section{Strengthening the Navy}

Indonesian Navy (TNI AL) occupies a strategic position and portion to seek optimum implementation of the world's maritime vision. Operating with the support of advanced Alutsista equipment will definitely accelerate the escort for the government to reachthe determined vision, to illustrate to other countries and to develop the implementation of diplomacy (naval diplomacy) effectively. The government and navy can make several efforts, including modernization, build up, and naval deployment. The growing dynamics also need to be a response for Indonesia in managing the achievement of the world's maritime vision. South China Sea Turmoil which so far has not found a bright spot yet, become a maritime land of Indonesia's maritime diplomacy. The preparation of strategic resources and the strengthening of the armed forces are an effective form of collaboration that should be put forward to the next ten years.

Analysis of Indonesia's maritime security is a deterrent as well as completion of various criminalities (terrorism, illegal trade, sea attacks, and people smuggling)in the territorial waters of Indonesia. Therefore, Indonesia needs to do various strategic steps, among others, that could be executed. They are:

1. Positioning international maritime security through Indonesian maritime strategic characteristics and values.

2. Developing strategic governance or maritime governance and country capabilities.

3. Protecting all Indonesian people, particularly those in the border region, by granting economic certainty gradually.

4. Arranging marine infrastructure and connectedness of trade routes, between the Indonesian Navy, regional and international levels.

5. Protecting the territories and the population from the danger of illegal organizations and crime and terrorism through the territorial waters. Especially those who located in vulnerable areas.

\section{CONCLUSION}

The Global Maritime Fulcrum Policy initiated by President Jokowi has several advantages and drawbacks. These advantages and threats make Indonesia think hard to realize the Global Maritime Fulcrum.

Indonesia' dream to realize the Global Maritime Fulcrum certainly must fulfill the 5 Pillars, particularly in the field of maritime economy and maritime defense as the sovereignty of the sea. The 5-pillar realization is an absolute requirement for NKRI to become GMF. The sovereignty of the sea includes two important things, completion of the maritime boundaries of NKRI and the maritime defense. Indonesia has geopolitical, geostrategic and demographic conditions that are very strategic and abundant natural resources so it is most likely to achieve the GMF.

\section{REFERENCES}

[1] Indonesia Sebagai Poros Maritim Dunia dalam http://www.presidenri.go.id/maritim/indonesiasebagai-poros-maritim-dunia.html diakses pada tanggal 15 Maret 2017.

[2] Saefuloh, Asep. Mewujudkan Agenda Prioritas Nawacita dalam http://berkas.dpr.go.id/puslit/files/buku lintas_tim/b uku-lintas-tim-14.pdf ${ }^{1}$ Callage, Hasarel. The Concept of National Power in International Relations dalam http://www.academia.edu/12790065/The_Concept_o $\mathrm{f}$ National_Power_in_International_Relations

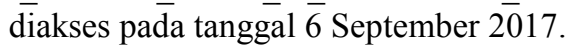

[3] Tindaon, Ferisman. Poros Maritim dan Revolusi Biru dalam http://harian.analisadaily.com/opini/news/porosmaritim-dan-revolusi-biru/80357/2014/11/10 diakses pada tanggal 5 September 2017.

[4] Mahan, T. Alfred. The Influence of Sea Power Upon History. Hal. 14. n.y

[5] Damuri, Yose Rizal. A Maritime Silk Road and Indonesia's Perspective of Maritime State . Ejournal CSIS WPPIR 201701 dalam https://www.csis.or.id/uploaded_file/publications/a maritime_silk_road_and_indonesia_s_perspective_o f_maritime_state.pdf diakses pada tanggal 5 Januari 2018.

[6] "Konsep Versi Sislognas Digugat", Bisnis Indonesia, 21Agustus 2014.

[7] S. Bahagia, Sandee H, Meeuws R. "State of Logistics Indonesia 2013, Collaboration Center of Logistics and Supply Chain Studies". Bandung: Institut Teknologi Bandung, Asosiasi Logistik Indonesia, Panteia, STC Group and World Bank, 2013.

[8] Kementerian Perencanaan Pembangunan Nasional/Badan Perencanaan Pembangunan Nasional, Buku I Agenda Pembangunan Nasional: Rencana Pembangunan Jangka Menengah Nasional 2015 - 2019, Jakarta: Bappenas, 2014, hal. 86.

[9] Bappenas dalam "Ini peta tol laut Jokowi program andalan bernilai puluhan triliun rupiah". http://beta.finance.detik.com/read/2014/11/19/07370 6/2752292/4/ini-peta-tollaut-jokowi-programandalan-bernilai-puluhan-triliunrupiah.

[10] Djauhar Manfaat, "Kontribusi Iptek Transportasi Laut Dalam Mewujudkan Poros Maritim Dunia", Makalah disampaikan pada Dialog Nasional Kontribusi Strategis Iptek untuk Mewujudkan Poros Maritim Dunia, 10 Desember 2014 dalam Lukman Adam. Kebijakan Konektivitas Maritim di Indonesia. Politica Vol. 6 No. 1 Maret 2015. hal. 28.

[11] Gandarsih, Iis dan Priamarizki, Adhi. Indonesia's Maritime Doctrine and Security Concern. Indonesia Program. Policy Working Paper. RSIS.2015. 